\title{
Expanding Learning Environment Through Mobile Learning
}

\author{
https://doi.org/10.3991/ijet.v15i07.13215 \\ Agus Purnomo ${ }^{(凶)}$, Bayu Kurniawan, \\ Khofifatu Rohmah Adi \\ Universitas Negeri Malang, Malang, Indonesia \\ agus.purnomo.fiseum.ac.id
}

\begin{abstract}
Technological developments change the point of view in learning. Learning space is not limited to conventional classrooms in schools. With technology, there is an opportunity to expand the learning environment through the development of mobile learning. This research design is the basic development of mobile learning in higher education. The purpose is to produce prototypes of online learning materials in physical geography courses. The test results are limited to one class showing positive responses from prospective users. Flexibility and ease of access make them able to learn according to the time they want. However, the limitations of this research are only limited to certain science courses, and it needs further development for social science courses.
\end{abstract}

Keywords-Mobile learning, learning materials

\section{Introduction}

The Industrial Revolution 4.0 provided significant changes in the world of learning. Especially in universities [1]. Many educational institutions are now trying to get out of the pattern of graduate printing through knowledge transfer into learning that can be determined by students themselves. The problem is that the changes that occur are not yet comprehensive in the learning process.

In simple terms, the idea of overhauling the curriculum can be applied to each subject. As in the application of a simple idea to investigate caterpillars in school trees conducted by elementary school children in San Diego, California [2]. The activity was then continued by opening a "caterpillar cafe" to provide education to their other friends. This gives students more knowledge and skills than teaching them about caterpillars through books. Learning conducted at the caterpillar cafe is done online in the form of instructing learning activities as a source of learning. The results of the learning activities are then communicated to share the knowledge they have acquired to form communication skills.

The success of the development that has been done [2] becomes rational that the need to change the pattern of teaching students in several subjects. Other preliminary studies have been conducted [3]-[5]. These changes lead to online-based learning that is equipped with modules to facilitate their learning activities. 
Online-based learning can be a solution to facilitate all students (expanding learning zones) in obtaining learning outcomes. Because what is conveyed by students in the classroom will not be fully accepted by students. There needs to be another way to guide them through the modules and online media presented in mobile learning.

\section{$2 \quad$ Literature Review}

Online learning tools that meet specific requirements must be compiled by experts in supporting learning activities, especially as a manual for learners in learning and for learners in learning for certain subjects [6]-[10]. In order to support learning activities, there need to be quality learning tools [11] to match the eligibility issued by the National Education Standards Agency (BSNP) which includes:

1) Content worthiness

2) Presentation

3) Linguistics

4) Graphic

The appropriateness of the content can be seen from several basic things expressed by the author to make students study [12]. The indicator refers to Willian Roman Models in analyzing module contents. The following indicators are intended:

1) How to express facts, principles, concepts, and definitions in writing

2) How many questions can attract attention, can be answered immediately, and build attitudes

3) Are there case studies that support learning outcomes or make activities to get answers.

All indicators of content eligibility described above are standard eligibility for module contents. The first three indicators are sections that examine how the writer presents the facts to the definitions in a book. The next three questions are part that examines whether the questions that exist not only build knowledge but also build attitudes. At the end is a study of how the writer writes a case as a description of the material in reality. The feasibility of the presentation has three leading indicators [13], namely:

1) Presentation technique

2) Presentation of learning activities

3) Completeness of presentation.

Indicators of presentation techniques focus more on the systematic review of the presentation. The measurements include:

1) The presentation systematics

2) The presentation thread

3) The balance between chapters. 
Indicators for the presentation of learning focus more on the study of learning scenarios that include:

1) Whether the learning process is student-centered,

2) Whether the learning scenario develops process skills, and

3) Whether the learning scenario prioritizes aspects of work safety (specifically on practice-based learning).

The completeness indicator of presentation refers to the preliminary, content, and closing components. Therefore the measurements include:

1) Is there an initial section that explains how to use books?

2) Is there a content section that is a core part of the book ?

3) Is there an ending section that provides a summary that students have achieved certain learning outcomes?

Language feasibility aims to examine whether the text presented is in accordance with the level of cognitive and emotional development of students who use [14]. Therefore language measurement indicators include: Does the language used in the text fit the level of intellectual, social-emotional development, and does not contain multiple meanings?

The feasibility of the graphic aims to examine whether the image used by the author to support the explanation is appropriate or not [12]. Measurement indicators include: Are the images used able to make it easier to understand explanations in the narrative, provide stimulation to carry out activities in accordance with their assumptions about the images, and facilitate them in carrying out procedures?

\section{$3 \quad$ Method}

The product development in this study uses the ADDIE Model, which consists of 5 stages namely, Analysis-Design-Develop-Implement-Evaluate. ADDIE emerged in the 1990s, developed by Reiser and Mollenda. One of its functions is to be a guideline in building useful and dynamic learning tools and infrastructure. This product development is limited to the fourth stage of the five stages of this model [15], namely:

\section{a) Analysis}

Analysis is the first stage that must be carried out by a learning developer. Three segments must be analyzed, namely students, learning, and the media to deliver teaching material. The steps in this analysis stage are at least:

1) Analyzing students' needs

2) Determining teaching material

3) Determining learning outcomes

4) Determining the media to be used. 


\section{b) Design}

The design is based on what has been formulated in the analysis phase. The design phase is analogous to the making of a learning plan. The plan must contain contact information, learning objectives, attendance requirements, work delay policies, learning schedules, directions, communication aids, technology policies, and an interface design for learning. The steps in this stage are making a plan which includes:

1) The module title

2) Determining the learning objectives

3) Determining the material description

4) Determining the learning strategy

5) Determining the learning resources

6) Determine the assessment instruments

\section{c) Development}

This stage is the stage of production where everything that has been made in the design stage becomes real. Steps in this stage include: creating learning objects such as

1) Learning materials

2) Learning activities

Both of these documents will be reviewed by material and media experts using predetermined instruments. The study was conducted in the FGD of the module readability test twice. The results of the first FDG will be a guideline for the authors to improve the quality of the module, and then verified in the second FGD as a form of product finalization.

\section{d) Implementation}

At this stage the learning system is ready to be used by students. The activities carried out in this stage are prepared to be used by students. This prototype will be tested in the even semester of the 2018/2019 school year according to the distribution of physical geography courses in the 2018 Social Studies Program Catalogue.

In the first application of the prototype will not be all enforced because there are needs to be a habituation of students to switch from offline learning to online learning. Of the 13 online modules that will be produced, we will try for four modules to find out its effectiveness.

\section{$4 \quad$ Result and Discussion}

\subsection{Product development}

Based on students' needs obtained from interviews, they need independent learning materials that can be accessed anytime they need. The learning characteristics of those 
who are not steady [16] need to be facilitated with more flexible learning patterns. These facilities can be in the form of online modules that can be accessed through their devices.

\section{a) Module}

The 13 online modules that have been produced are supporting students to study independently outside the classroom. Independent learning is an expansion of learning space that they can use to do worksheets. The 13 modules are used at meetings 2-7 and 9-15. The resulting module is uploaded to google classroom, which access has been shared with students at the first meeting so that they can directly download it independently through the existing device.

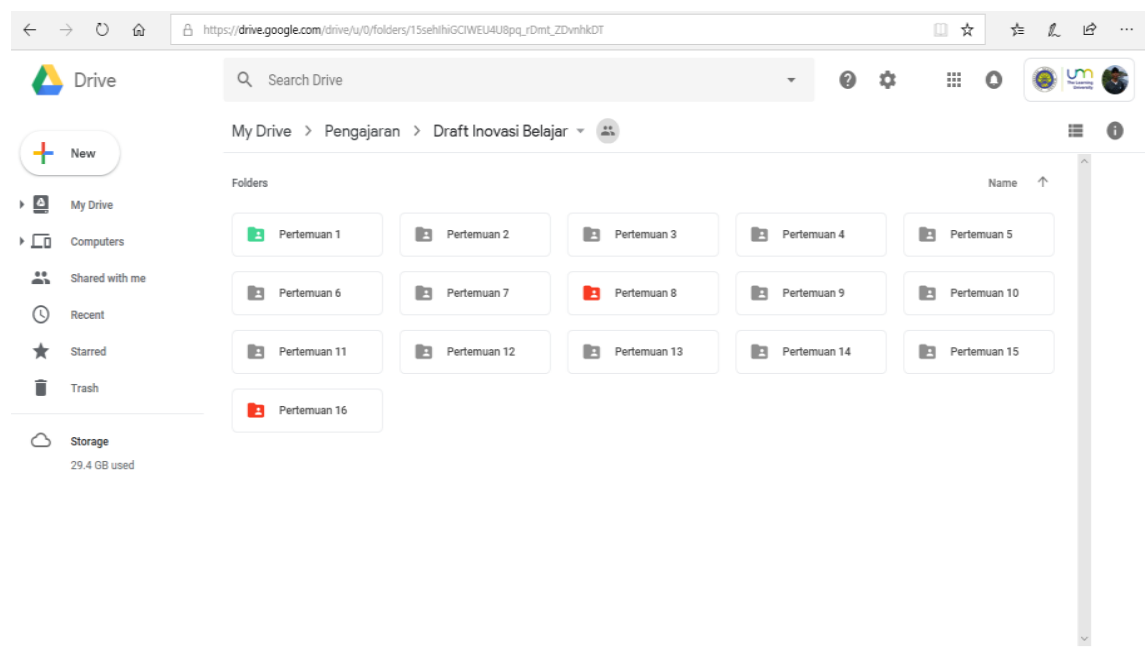

Fig. 1. The online class folder in google classroom physical geography courses

The module is used from the second meeting because the first meeting is used to equalize perceptions about learning to be carried out, including access to a google classroom account. At the first meeting, a guided simulation was conducted to open access to the online class provided and how to upload work in the classrooms provided.

Online classes can be accessed through a computer or a connected to the internet network smartphone (fig 1). They will independently download the reading material provided and work on the worksheet according to the instructions. The worksheet results will be uploaded in the space provided.

\section{b) Worksheet}

There were 18 worksheets produced in this development, all worksheets aimed at building knowledge, attitudes, and skills. On the worksheet, there are instructions for building the three domains. Worksheets are downloaded and done before the class so that when the meeting takes place, it is more focused on discussing the results of work 
and strengthening the knowledge, attitudes, and skills of the results that have been done.

Each worksheet will support the development of knowledge, attitudes, and skills found in the online module. Most FIs are done in groups to build communication skills within the network while upholding the value of politeness. There is a discussion facility through the add comment menu that can be used by students if they have difficulty in doing worksheets.

Some worksheet prioritizes building experience for dialogue with interdisciplinary disciplines such as sociology or history as in worksheet 11 at the ninth meeting.

Other worksheets also try to build student empathy with others. Namely at worksheet 13 Earthquake Disaster Preparedness at the 11 th meeting (fig 2). In this worksheet, it is simulated if in certain conditions an earthquake occurs, what should they prioritize to do.

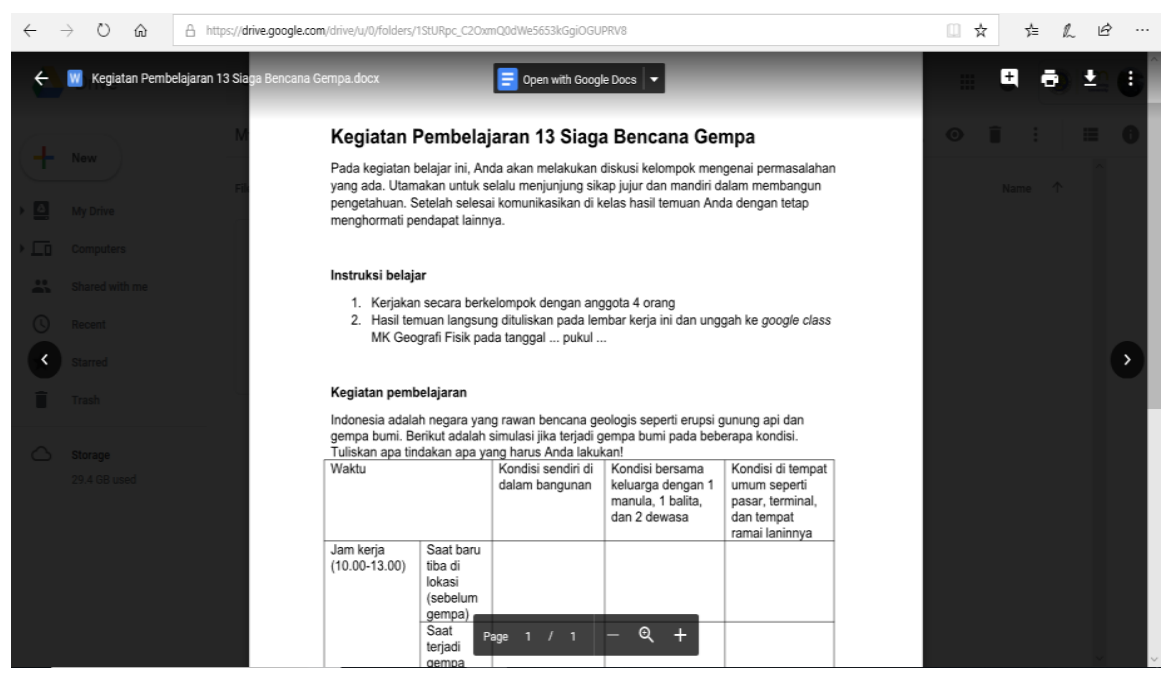

Fig. 2. The online worksheet on physical geography courses

\section{c) Evaluation}

The evaluation package is a collection of evaluation questions that refer to the module, and the goal is to measure the learning achievements that have been carried out by students. There are four types of questions, namely:

1) Multiple-choice

2) True-false

3) Short answers

4) Description.

The evaluation package is a question bank that can be used to prepare learning evaluations in physical geography courses. Problems can be applied using conventional methods such as paper and pencil tests or using the internet so that they can be 
done through devices owned by students. Google form is a single facility that can be used to conduct online evaluations (fig 3).

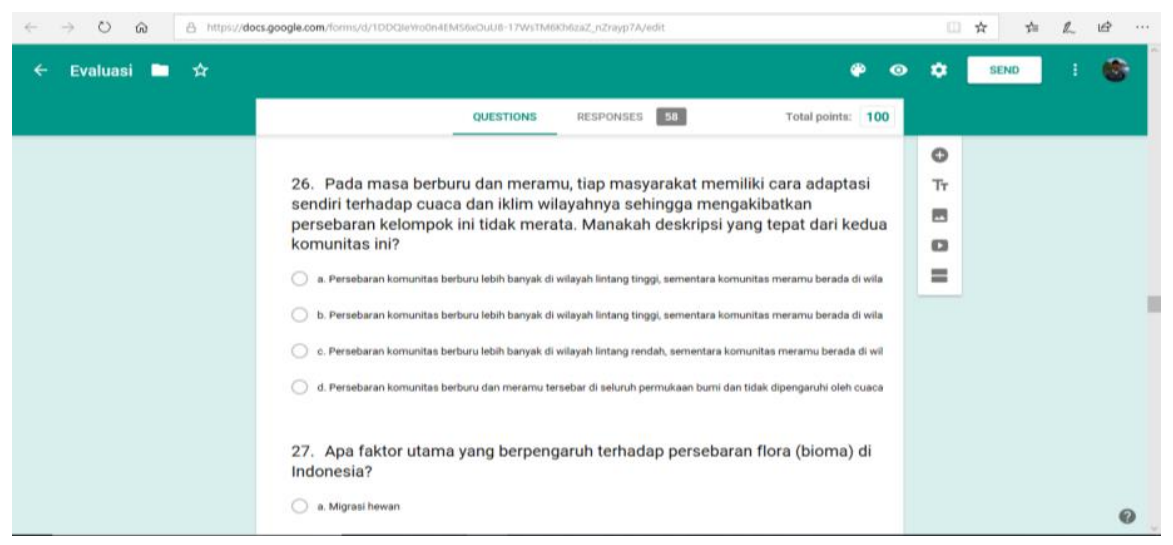

Fig. 3. The online evaluation on physical geography courses

\subsection{Study the results of development}

The module was reviewed by two validators and tested for readability by 10 prospective users of Social Sciences Faculty of Social Sciences S1 students. The module study results show that the average value of the 13 modules is 95 , meaning that the module is very good so it is suitable for publication. The results of comments from validators and prospective users indicate that this module has a level of readability that is easily to be understood. Look at table 1 . about the recap of the study results and module readability test.

Table 1. Recapitulation of Study Results and Module Readability Tests

\begin{tabular}{|c|l|}
\hline No & \multicolumn{1}{|c|}{ Improvement comment from validator } \\
\hline 1 & Writing modules uses simple language and is equipped with examples \\
\hline 2 & $\begin{array}{l}\text { The existing examples are still not too concrete but because the primary objectives provide } \\
\text { broader insights and have been facilitated by LK for contextual material and examples }\end{array}$ \\
\hline 3 & $\begin{array}{l}\text { The number of questions between modules is still not consistent even though the type of problem } \\
\text { is uniform across all modules }\end{array}$ \\
\hline 4 & The final part of the module is able to provide a broader picture of the material being studied \\
\hline 5 & $\begin{array}{l}\text { LK is enough to build a cooperative attitude and build empathy, but there needs to be a more } \\
\text { detailed explanation of worksheet work to make it easier for students }\end{array}$ \\
\hline 6 & $\begin{array}{l}\text { The picture illustrations in the explanation already have the readability and originality of the } \\
\text { author }\end{array}$ \\
\hline 7 & $\begin{array}{l}\text { The material presented already illustrates the learning objectives and the form of evaluation is } \\
\text { sufficient to measure the achievement of learning outcomes }\end{array}$ \\
\hline
\end{tabular}

The convenience offered in the form of learning flexibility gives a positive value to the product produced. Using a user-friendly platform also speeds up the process of user habituation. Through this platform they independently access learning resources 
that have been provided, this activity builds independent character in learning [17], [18]. Independence in learning will bring positive influence in the whole process of their lectures. The habits of learning independence help them to determine long-term learning targets [19], [20].

\section{Conclusion}

There are three products produced from this development, namely modules, worksheets, and evaluation questions. At this initial stage, product prototypes gets positive responses from media and material experts. Some deficiencies such as minor technicalities and adding real examples into minor improvement notes without changing the structure of the product. However, it is necessary to follow up gradually to implement it in order to measure the effectiveness of its users on real users. The aspect of this product can broaden the definition of the learning space. Study space is not only limited to class buildings. Now classes can be changed in digital form with communication patterns shifted into virtual form.

\section{References}

[1] H. Prasetyo and W. Sutopo, "Industri 4.0: Telaah klasifikasi aspek dan arah perkembangan riset,”J@ti Undip J. Tek. Ind., vol. 13, no. 1, p. 17, Mar. 2018. https://doi.org/10. 14710/jati.13.1.17-26

[2] M. Jenkin, "Inside the schools that dare to break with traditional teaching," 2015. [Online]. Available: https://www.theguardian.com/teacher-network/2015/feb/11/schools-studentstraditional-teaching. [Accessed: 19-Nov-2019].

[3] W. Lin, "Exploring the convergence of the mobile learning mode in network environ-ment and the traditional classroom teaching mode," Int. J. Emerg. Technol. Learn., vol. 12, no. 7, pp. 170-181, 2017. https://doi.org/10.3991/ijet.v12i07.7248

[4] B. Hariadi, M. J. D. Sunarto, P. Sudarmaningtyas, and B. Jatmiko, "Hybrid learning by using brilian applications as one of the learning alternatives to improve learning outcomes in college,” Int. J. Emerg. Technol. Learn., vol. 14, no. 10, pp. 34-45, 2019. https://doi.org/ 10.3991/ijet.v14i10.10150

[5] I. K. Suartama, P. Setyosari, Sulthoni, and S. Ulfa, "Development of an Instructional Design Model for Mobile Blended Learning in Higher Education | Suartama | International Journal of Emerging Technologies in Learning (iJET), " International Journal of Emerging Technologies in Learning, 2019. [Online]. Available: https://onlinejournals.org/index.php/ i-jet/article/view/10633. [Accessed: 19-Dec-2019]. https://doi.org/10.3991/ijet.v14i16. $\underline{10633}$

[6] Loveridge, Cornelsen, Lewis, and Terekhov, Preparing textbook manuscripts: a guide for authors in developing countries - UNESCO Digital Library. 1970.

[7] Tarigan, Henry Guntur, Tarigan, and Djago, Telaah buku teks bahasa Indonesia / Hen-ry Guntur Tarigan, Djago Tarigan; penyunting, Tim Penyunting Angkasa | OPAC Perpustakaan Nasional RI. 2009.

[8] B. P. Sitepu, Penulisan Buku Teks Pelajaran. PT Remaja Rosdakarya, 2012.

[9] M. Masnur, Text book writing: dasar-dasar pemahaman, penulisan, dan pemakaian buku teks | OPAC Integrasi | Online Public Access Catalog | Universitas Gadjah Mada. 2016. 
[10] O. W. Puspita, Andayani, H. J. Waluyo, and M. Rohmadi, "A Needs Analysis for Po-etry Appreciation Textbooks in Universitites: An Exploratory Study,” Am. J. Educ. Res., vol. 5, no. 4, pp. 357-361, 2017.

[11] S. S. Asri, "Telaah Buku Teks Pegangan Guru dan Siswa pada Mata Pelajaran Bahasa Indonesia Kelas VII Berbasis Kurikulum 2013," RETORIKA J. Ilmu Bhs., vol. 3, no. 1, p. 70, Jul. 2017. https://doi.org/10.22225/jr.3.1.94.70-82

[12] Khatoon Vakili and Zahra Mansouri, "A Study on the Content Analysis of Social Stud-ies Textbook of Sixth Grade Elementary School: According to William Roman Technique," pp. 3034-3037, 2016.

[13] R. Rismawati, Rustono, and A. Nugraha, "Pengaruh Penggunaan Model Pembelajaran Kooperatif Tipe Jigsaw terhadap Hasil Belajar IPS Siswa Kelas IV di Sekolah Dasar | Rismawati | PEDADIDAKTIKA: Jurnal Ilmiah Pendidikan Guru Sekolah Dasar," PEDADIDAKTIKA: Jurnal Ilmiah Pendidikan Guru Sekolah Dasar, 2017. [Online]. Avail-able: https://ejournal.upi.edu/index.php/pedadidaktika/article/view/7425. [Accessed: 31-Oct-2019]. https://doi.org/10.26740/jrpd.v5n1.p868-874

[14] Y. Hendrawanto and M. Mulyani, "Kelayakan Kebahasaan dan Isi Buku Teks Bahasa Indonesia Kelas XII Semester 1 SMA,” JP-BSI (Jurnal Pendidik. Bhs. dan Sastra Indones., vol. 2, no. 2, p. 58, Oct. 2017. https://doi.org/10.26737/jp-bsi.v2i2.246

[15] K. Shelton and G. Saltsman, "Using the Addie Model for Teaching Online," Int. J. Inf. Commun. Technol. Educ., vol. 2, no. 3, pp. 14-26, 2006.

[16] A. Dolot, "The characteristics of Generation Z," e-mentor, no. 74, pp. 44-50, Oct. 2018.

[17] A. Purnomo, N. Ratnawati, and N. F. Aristin, "Pengembangan Pembelajaran Blended Learning Pada Generasi Z," J. Teor. dan Praksis Pembelajaran IPS, vol. 1, no. 1, pp. 7076, Apr. 2016. https://doi.org/10.17977/um022v1i12016p070

[18] A. Purnomo, B. Kurniawan, and N. Aristin, "Motivation to Learn Independently through Blended Learning," in the International Conference on Educational Research and Innovation (ICERI 2018), 2019. https://doi.org/10.2991/iceri-18.2019.55

[19] C. Silen and L. Uhlin, "Self-directed learning - A learning issue for students and faculty!,” Teach. High. Educ., vol. 13, no. 4, pp. 461-475, Aug. 2008. https://doi.org/10.1080/ 13562510802169756

[20] M. Ponton, R. H. Reysen, N. Wiggers, and T. Eskridge, "International Journal of SelfDirected Learning,” Int. J. Self-Directed Learn., no. December, 2017.

\section{$7 \quad$ Authors}

Agus Purnomo is a lecturer in the Social Studies Department Faculty of Social Science Universitas Negeri Malang. His primary interest is in tourism and mobile learning research. He is the editor-in-Chief of the journals JTPPIPS at journal2.um.ac.id.

Bayu Kurniawan is an Indonesian Historical Education, one of the lecturers in the Faculty of Social Science, Universitas Negeri Malang. His research interest is education and learning innovation.

Khofifatu Rohmah Adi is an Economic Education, one of the lecturers in the Faculty of Social Science, Universitas Negeri Malang. Her research interest is education and green economy.

Article submitted 2020-01-17. Resubmitted 2020-02-19. Final acceptance 2020-02-19. Final version published as submitted by the authors. 